\title{
Onwards and Upwards with Women in the Gulf
}

\author{
by Andrew Leber, Charlotte Lysa | published January 11, 2018
}

Change is afoot for Saudi Arabia's female citizens, or so suggests much commentary about events over the past few years. There was the first election in which women could vote, the first public concert by a female performer, and soon (if all goes according to plan) for the first time Saudi women will be able to drive on the streets of Riyadh and elsewhere in the kingdom. All have garnered their share of headlines.

Rulers in the Arab Gulf monarchies, including Saudi Arabia, seem well aware of the spotlight grabbing power of historic "firsts," in which the power to effect change seems to derive from the hand signing the latest decree. This September, Saudi Arabia's interior ministry quickly warned activists away from speaking to the press about any role they might have had in ending the driving ban, so determined were they to see media narratives of a changing kingdom driven by references to "modernizing monarchs"-chiefly the oft-profiled Crown Prince Muhammad bin Salman.

As Saudi scholar Hala al-Dosari noted in an interview regarding the announcement on women driving, "[i]n order to gain an alliance with international powers, they [the Saudi government] need to normalize certain issues-but not too much, not to the point that it's transforming the structure that lends them power." [1] Thus, while a Gulf version of "state feminism" appears increasingly in vogue, rulers in Saudi Arabia appear unwilling to share the stage with those Saudi activists who kept the issue a source of international embarrassment for the Saudi government over the years: Manal al-Sharif, Loujain Hathloul, Maysa al-Amoudi and Eman al-Nafjan, all of whom have repeatedly filmed themselves driving since 2011, as well Aisha al-Mana and Fawzia al-Bakr who joined 45 other women to drive through central Riyadh as far back as 1990.

There is ample reason for activists to press on regardless of the latest decree. Despite its wealth, Saudi Arabia joins fellow Arab monarchies of the Gulf-Oman, Qatar, Bahrain, Kuwait and the United Arab Emirates-in the bottom third of the World Economic Forum's Gender Gap survey, with restrictive "guardianship laws" that limit female citizens' right to free movement, divorce and child custody. [2] Women make up only around one-third of the citizen workforce in Saudi Arabia, growing even scarcer in high-ranking positions, mirroring the situation in Oman and Qatar. [3] At the same time, limited mobility for women and a complete lack of physical education programs in schools have been cited as contributing to high rates of obesity, diabetes and hypertension among Saudi women relative to men, despite a disappearing gap between women's and men's education. [4]

Moving beyond a controlled narrative of steady, measured change, journalists and academics can work to do justice to the everyday struggles of Saudi women and their peers around the Gulf to secure new opportunities for their themselves and their fellow citizens. As al-Dosari has noted, charting frustrations with the slow pace of progress for women's rights in the region, "it's important to not think it all hinges on what one person says or doesn't say, does or doesn't do. Each person's work is a piece of the puzzle." [5]

In trying to piece together the puzzle of women's activism and social movements in Saudi Arabia, experiences elsewhere among the Arab Gulf monarchies might provide some insight. Such is the guiding philosophy of WEORITU, a Kuwaiti organization that criss-crossed the Gulf Cooperation Council (GCC) countries to film more than 130 interviews with women, trying to create shared knowledge of women's advances in the region. [6] Despite valuable single-country case studies, such as Madawi al-Rasheed's The Most Masculine State and Amélie Le Renards's A Society of Young Women, little comparative work has sought to leverage variation among the GCC countries to generate insights about gendered aspects of political and social change. 
To be sure, it is fair to question whether any country's historical trajectory is close enough to another, let alone to Saudi Arabia, to convincingly compare. Esraa al-Amiri, a genderequality activist and Kuwaiti lawyer, was skeptical of trying to transplant "lessons learned" from Kuwait: "We mostly try to connect with activists from outside the Gulf," she said. "The Gulf countries [other than Kuwait] don't have civil societies to the same degree." [7] Yet, with allowances made for potential confounding factors, it is hard to think of a cluster of cases better matched in terms of political economy, political systems and culture from which to derive "portable truths" about contentious politics and policy change.

With this in mind, an examination of women's struggles to gain the right to vote in Kuwait, and ongoing efforts to promote women's football in Qatar, provide useful in-depth case studies. They cannot predict the future course of change in Saudi Arabia, but they illustrate the need for ongoing political engagement and social activism to secure gains, and the limitations of state-led efforts to remake isolated aspects of Gulf societies while failing to reckon with the complex web of social regulations that underpin present gender divides.

\section{Political Change in Kuwait}

A decade before Saudi women gained the right to vote and run in elections for the kingdom's (relatively toothless) municipal councils, Kuwaiti women garnered headlines worldwide when a law granting women's suffrage cleared the country's elected National Assembly. While the existence of a powerful, elected parliament contrasts sharply with the closed-off Saudi political system, the interplay of local civil society and international scrutiny-along with the disappointments that followed initial victory-suggests important parallels with present developments in Saudi Arabia.

A decades-long mobilization of women's groups and allies had long pressed the Kuwaiti monarchy for expanded political rights, working with the elected parliament when possible. Even before prominent activist Nouria al-Saddani began petitioning for greater political rights in the 1970s, Kuwaiti women organized to press for greater social and political participation, through organizations such as the Arab Women's Development Society (AWDS)-later disbanded by the government for its vocal campaigning-and the Women's Cultural and Social Society (WCSS). Although claims that the Kuwaiti government and parallel Islamist women's organizations had co-opted and sidelined these organizations by the mid-1990s, the Iraqi occupation of Kuwait in 1990-1991 set the stage for a sustained push for women securing the right to vote.

During the occupation, well-connected female activists lobbied governments abroad on behalf of the country to intervene and organized protests and community resource networks. Upon his return from exile, then-Emir Jaber al-Ahmad Al Sabah publicly acknowledged the "supreme and bright role that women undertook" during the occupation, while even the conservative Crown Prince Saad noted that the Kuwaiti women's patriotic role "undoubtedly entitles her to an even greater role... in the Kuwait of the future." [8] As once-and-future head of the WCSS Lulwa al-Mulla noted, Kuwaiti women relied on these speeches to hold the ruling family to account for their promises. "In the Emir's speech in the UN and the Jeddah conference, they said that Kuwaiti women should take their rightful place in liberated Kuwait...we relied on the 29th article of the constitution [guaranteeing equality] and the speeches of the Emir. You said that women should take their political rights in liberated Kuwait!" [9]

Henceforth, the path to attaining women's suffrage in Kuwait was a dialectic of maneuvering between women's groups and allies among liberal political groups and members of parliament, for whom women obtaining the right to vote was both an ideological goal and a source of a potential advantage at the polls. Political organizing alone seemed unable to force the issue, yet neither could the royal family be counted on to quickly override conservative voting blocs in parliament as a means of boosting international legitimacy. 
Most notably, Emir Jaber granted women the right to vote amid a host of other unilateral decrees after dissolving parliament and calling for new elections in 1999, hoping that some returning opposition MPs would go along with such a power grab as long as it was in the service of "liberal" aims. With a determined opposition, however, and a ruling family unwilling to spend much political capital on the issue (wary of antagonizing loyalist conservative and Islamist MPs), the motion failed by just two votes.

The matter was returned to consideration in 2004, this time backed by a royal prime minister willing to pull out all the stops to get the vote through the Kuwaiti National Assembly-Sheikh (and future Emir) Sabah al-Jaber Al Sabah, who replaced his ailing second cousin Sheikh Saad. Having long served as foreign minister, Sheikh Sabah put a high value on boosting Kuwait's profile internationally and was constantly reminded of the denial of women's suffrage at international conferences and in interactions with the United States, a key foreign power.

Yet even if, as political scientist Eleanor Doumato once quipped, women's rights in the Gulf were "the gift of kings, not parliaments," female Kuwaiti activists helped maintain pressure on the Kuwaiti ruling family to follow through on its "gift." Rola Dashti, one of Kuwait's first female parliamentarians, recalled a meeting with then-Sheikh Sabah during the early 2000s to discuss the international pressure Kuwait was under regarding women's suffrage. "I remember the emir - then the prime minister - was telling me 'With all your efforts, do you know what they are telling us? That Kuwait is not a democratic country!' And so I said, 'Well, Your Highness, give us our rights and you will not hear of this again!" [10]

In the end, the National Assembly granted women the right to vote in May 2005, with the speaker of the parliament confiding to US diplomats that the outcome was because Sheikh Jaber "was determined and got what he wanted"-declining to elaborate on what were almost certainly direct financial or political bribes to several MPs. [11] Still, the decade since has seen a great deal of frustration with the slow pace of change. With the unifying goal of securing the right to vote gone, more conservative women's organizations ceased to identify as "women's groups," with some individuals feeling resentful that they had effectively been written out of the narrative of resistance. Aroub al-Rifa'i-one such woman from the Islamist-leaning organization Bayadir al-Salam, who joined forces with liberal activistspointed to structural problems in Kuwaiti politics forestalling action on a wide range of issues. "The emir's powers need to be constrained, while the powers of the ministers need to increase-and there need to be political parties, with the parties choosing the prime minister." [12]

The parliament is now a source of concern as much as a focus of Kuwaiti women's political ambitions While available evidence suggests that women will vote for women-Safaa alHashem garnered the highest proportion of women's votes in the latest round of elections for her district-the belief remains that nothing short of a quota will encourage broader women's representation in the parliament. The National Assembly's sole female member of parliament at present, Safaa, falls far short of the four elected in 2009. While the presence of those four women and their successors undoubtedly affected policies in Kuwait that had disadvantaged women-Rania Maktabi documents resulting changes to women's ability to access social insurance payouts, passports and public housing-progress has been slow on women being able to grant non-Kuwaiti spouses and any resulting children citizenship rights, in addition to addressing matters of domestic violence and abuse. [13]

The need to drive change from below, or defend against backsliding, seems constant. The unwillingness of tribal and Islamist groupings to field female candidates and the seeming inability of liberal political groupings to accept female politicians into their inner governing structures (or even engage in electoral fights in recent years) is not helping matters. Conservative factions in the National Assembly have even appropriated the language of 
"women's rights" to push for an even lower retirement age for women, incentivizing female citizens away from lengthy and fruitful careers through state largesse. Alanoud Alsharekh and others have launched the Abolish 153 campaign to try to eliminate extremely light sentencing for perpetrators of "honor killings," yet despite garnering international human rights attention and lobbying members of parliament with polling evidence on citizens' opposition to the existing legal code, an official government response is only slowly gathering steam.

The experience of Kuwait suggests a long and frustrating road ahead for women's empowerment in Saudi Arabia, which is made all the more frustrating by the fact that there are few channels for any organized dissent, in contrast to the relatively open public sphere in Kuwait. Within days of the announcement of women's impending right to drive in Saudi Arabia, for example, snickering memes had already begun to appear on Twitter mocking the silliness of the proposition-no doubt playing a role in the kingdom's swift announcement that anybody mocking a certain "royal decree" would soon face a hefty fine. It likewise remains to be seen whether the right to drive is granted as a one-off concession to boost the kingdom's standing abroad, or stands to drive yet more reforms in the future. Even under the "liberalizing" tenure of Muhammad bin Salman, several women appointed to the kingdom's Shura (Advisory) Council tendered their resignations out of a belief that they were serving as little more than figureheads, and that their proposals to improve the status of women in Saudi Arabia were falling on deaf ears. [14]

\section{Kickoff from Above?}

Women's sports is another case where a long process of partial successes and frequent setbacks lies behind major headlines. Saudi Arabia received much coverage when it bowed to international pressure and sent its first female athletes to the Summer Olympics in 2012, along with Brunei and Qatar. Athletes Wojdan Shaherkani (in judo) and Sarah Attar (in track and field) did not qualify for the games, but participated on special invitation from the IOC in events that still garnered massive media attention. These developments alone did little to change attitudes toward female sports participation back home, however. Four years on, female Saudi athletes participating in the Rio Olympics still had little institutional support while some even lacked proper sports facilities in their home country. Recent initiatives to increase women's participation in sports and physical activities are especially timely.

In neighboring Qatar, where similar social norms and religious doctrines prevail, efforts to include women in sports have a longer history. Despite significant differences between the two countries, experiences from Qatar to promote female athletic participation shed light on the complex challenges Saudi Arabia will have to face even in an organized "revolution from above" in women's sports.

Since the turn of the millennium, and especially after being awarded hosting rights to the FIFA World Cup 2022 in 2010, there have been several official initiatives aimed at increasing the number of women in Qatar (and Qatari women specifically, given the high number of expatriates in the country) who actively participate in competitive, organized sports. The Qatar Women's Sports Committee (QWSC) was formally established by royal decree in 2001, with an aim of encouraging female sports participation and improving women's performance. In 2006, when Doha hosted the Asian Games, golfer Shurouq al-Suwaidi became the first woman to represent the country at a major sporting event. When Qatar came under heavy international pressure to send its first female athletes to the Summer Olympics in London in 2012, they chose a woman, shooter Bahiya al-Hamad, as the country's flag bearer to express their genuine interest in promoting female athletes. Instead of sending the two asked for by the organizers, Qatar sent four, all admitted on wild-card status rather than gaining admission through competitive play. 
Top down initiatives, however, cannot alone provide a quick fix for all of the factors preventing Qatari women from participating in sport. For example, the Qatari women's basketball team withdrew from the Asian Games in 2014 not due to a lack of home country support but because of an organizational ban on wearing the hijab. Despite mounting formal opportunities, strict social norms remain, as does the "opportunity gap" for men and women to engage in sports and physical activity. This is especially the case with professional or competitive sports, which presupposes a certain kind of exposure from a young age. According to Susan Dun, one of the main state-led strategies for greater women's participation in sports is to link women's physical activity to elite sports participation by promoting female sportswomen in local media. However, as Dun points out, there are still Qatari families who would frown on female family members showing their face in the media at all. [15] These kinds of attitudes might help explain why even though football has been played in Qatar since the 1940s, and the QWSC was set up in 2001, it was not until 2010 (the year Qatar placed its bid for the World Cup) that a women's national team was first established.

Women's own experiences as football players in Qatar since the formation of the national team exemplify the potential limits of top down policies for improving women's rights in the GCC region. Despite efforts by the Qatari government to encourage female sports, players and coaches note that recruitment is still difficult. There is certainly an interest in playing among young women, yet Qatar remains a conservative society where such change is confronted by traditional ideas about a woman's defined role in society. While governmental initiatives can break down logistical barriers and provide the infrastructure for sport, they do not offer a quick fix for the resistance of social structures reified by other aspects of government policy-such as laws that help keep patriarchal authority paramount within families.

For would-be female football players then, this poses an obstacle to their active participation-playing football in public can hardly be done anonymously or covertly. For many Gulf women interested in playing competitive sports, their fight is not necessarily for the right to play on a national team, or even any kind of professional league, but rather to participate at all. "Girls want to play football. That's it! It's not about, 'Oh, I want to make a career out of this.' I mean, if I were a boy, I would have gone for it because football is one of my biggest passions. But it would never happen," said a Qatari female footballer last year. [16]

Instead of refraining from playing, women create private arenas to play away from public scrutiny, like renting fields closed for men at university premises. When female students who want to play competitive football decide to set up their own teams, a priority to keep the environment "male-free" means playing indoors. The women's basketball teams of Education City play in front of a mixed male and female audience, and it is therefore rare to find any Qatari players. Another tactic is to keep the activity inside the university premises, a space trusted by their families. By maneuvering around societal norms and gendered expectations inside such a "safe space," players create opportunities where women can be footballers, and where customary ideas about sports as inherently masculine can be challenged.

For some, this is a pragmatic dodge, a socially acceptable alternative to not playing at all, while others do so out of personal belief in religious or cultural modesty. In Doha's Education City, a large compound consisting of a number of institutions including six satellite campuses for prominent American universities, female students have built their own football league. In contrast to the public Qatar University, Education City is not gender segregated and the educational language is English. This environment attracts (as various institutions admit) only a certain part of the population, including children of long-term expatriats and American students studying abroad. The Qatari female students typically 
come from a background described as "open," or more socially liberal. In Qatar, which has a small and often conservative native population linked by dense tribal and family ties, it can be quite hard to break with social norms even if immediate family has a different attitude. For example, a mixed gender service trip to Brazil with several young Qataris sponsored by Vodafone was quickly abandoned by the company in the face of social media backlash over women travelling unaccompanied by family and failing to wear "proper attire." [17]

Despite these challenges, subtle shifts that make more physical spaces available to women's athletics in the region hold much promise. In Saudi Arabia, for example, a quiet change has been the expanded licensing of women's sports facilities, following the appointment of Princess Reema bint Bandar al-Saud as vice president for women's affairs at the General Sports Authority in Saudi Arabia. She is a vocal advocate of expanded rights for women in the kingdom. Already, the Sports Authority has said that football stadiums, until 2017's National Day celebration exclusively reserved for men, would be renovated to include family sections to give women regular access. Until very recently all governmental sporting facilities have been licensed to allow men only, effectively banning families, women and young girls from taking part in athletics, even as spectators. Some women's gyms known to operate with faulty licenses or none at all have started the process to formally register, while new gyms and even entire athletic chains are popping up at an impressive pace, and filling up even faster. As one gym manager noted, "Opening up for the licenses has caused gyms to pop up right and left-it is the hot industry to go into. Because it's a virgin market, everyone wants a piece of the cake." [18]

While these efforts might not be as headline-worthy as competing in the Olympics, the work by passionate individuals to help carve out and maintain spaces for future participation lay the groundwork for advances in ways that extend beyond a mere public relations enterprise. As one player said, "It is part of a change. It is an awakening. It is like, the roots of the future. It's like planting a seed for a garden you will never see. It's not going to be easy, and it's not going to be our generation that will see it." [19]

\section{Discussion}

Media outlets might report an occasional "first" or highlight a viral video regarding the status of Saudi women, such as a flurry of articles on Saudi male director Majed Al-Esa's provocative video "Hawajis" (Concerns) that mocked the ban on driving. [20] Yet only a few outlets, such as Bloomberg and its in-region reporters, manage to convey the history of social change beyond a simple narrative of "modernization" over time. With each report on "the first Saudi woman to do X" and each treatise on how Gulf women's rights evolved or advanced at a specific time or place, we lose an opportunity to understand how the dynamics of the region's politics and societies variously come together to expand opportunities for female citizens or subject them to new restrictions-to say nothing of the immense barriers facing many female expatriate workers in the region.

Women's movements may be more effective at driving social change when they target concrete goals with broad appeal, such as securing sports infrastructure or simply exercising together in Saudi Arabia, then when they openly seek to smash the patriarchy per se. Likewise, as the experience of Aroub al-Rifai and other conservative women in the Kuwaiti suffrage movement suggests, understanding the motivations and perceptions of Gulf women beyond a limited circle of liberal activists can provide a richer account of the role that a wide range of Gulf women play in transforming or maintaining Gulf societies. It is time to move beyond a narrative that "traditional" women lack agency or even a basic willingness to shape the world around them. Better arguments and sounder explanations regarding the changing status of women in Saudi Arabia, and the Gulf countries more broadly, cannot come soon enough. 


\section{Endnotes}

[1] Sigal Samuel, "A Saudi Woman's 'Mixed Feelings' About Winning the Right to Drive," The Atlantic, September 27, 2017.

[2] World Economic Forum, Gender Gap Report, 2016 Rankings.

[3] Sultanate of Oman, 2017 Statistical Yearbook; Qatar Labor Force Survey, Q3 (July-Sept 2017).

[4] Mashael K. Alshaikh, Filippos T. Filippidis, Hussain A. Al-Omar, Salman Rawaf, Azeem Majeed and Abdul-Majeed Salmasi, "The ticking time bomb in lifestyle-related diseases among women in the Gulf Cooperation Council countries; review of systematic reviews," BMC Public Health, June 2017.

[5] Author interview, January 11, 2017.

[6] WEORITU, "Women from the Middle East (GCC) unite to say: نحن قادرات WE CAN DO IT." Available: https://www.youtube.com/watch?v=91vmDnDI4Oc.

[7] Author interview, February 11, 2017.

[8] Both quoted in "Kuwait," World Report 1992, Human Rights Watch, 1992.

[9] Author interview, Kuwait City, January 3, 2017.

[10] Author interview, Kuwait City, December 26, 2016.

[11] Embassy Kuwait, "Assembly Speaker Surprised by Vote on Women's Rights; Restates

Kuwaiti Support For Itg." Wikileaks Cable: 05KUWAIT2173_a. May 22, 2005.

[12] Author interview, Kuwait City, December 28, 2016.

[13] Rania Maktabi, "Female Citizenship and Family Law in Kuwait and Qatar: Globalization and Pressures for Reform in Two Rentier States," Nidaba, 1 (2016).

[14] "Departure of four women from Shura who asked to be excused - one left in place," Okaz, December 4, 2016. [Arabic]

[15] Susan Dun, "Role Models in the Media and Women's Sport Participation in Qatar," Nidaba 1 (2016).

[16] Author interview, Doha, November 14, 2016. [17] Elysia Windrum, "Qataris' Amazon Adventure to Continue After Vodafone Withdraws Support," Doha News, August 18, 2014.

[18] Author interview, Riyadh, October 24, 2017.

[19] Author interview, Doha, November 14, 2016.

[20] Majed Al-Esa, "Hawajis." Available: https://www.youtube.com/watch?v=1rUn2j1hLOo. 